\title{
Dietary effects on body weight of predatory mites (Acari, Phytoseiidae)
}

\author{
Authors: Irina Goleva, Esteban C. Rubio Cadena, Nar B. \\ Ranabhat, Caroline Beckereit, and Claus P.W. Zebitz
}

NOTICE: this is the author's version of a work that was accepted for publication in Experimental and Applied Acarology. Changes resulting from the publishing process, such as peer review, editing, corrections, structural formatting, and other quality control mechanisms may not be reflected in this document. Changes may have been made to this work since it was submitted for publication. A definitive version was subsequently published in Experimental and Applied Acarology, [VOL\# 66, ISSUE\# 4, (August 2015)] DOI\# 10.1007/s10493-015-9920-5 Creative Commons Attribution Non-Commercial No Derivatives License

Goleva, Irina, Esteban C. Rubio Cadena, Nar B. Ranabhat, Caroline Beckereit, and Claus P. W. Zebitz. "Dietary effects on body weight of predatory mites (Acari, Phytoseiidae)." Experimental and Applied Acarology 66, no. 4 (August 2015): 541-553.

https://dx.doi.org/10.1007/s10493-015-9920-5.

Made available through Montana State University's ScholarWorks scholarworks. montana.edu 


\title{
Dietary effects on body weight of predatory mites (Acari, Phytoseiidae)
}

\author{
Irina Goleva ${ }^{1} \cdot$ Esteban C. Rubio Cadena $^{1} \cdot$ Nar B. Ranabhat $^{1,2}$ \\ - Caroline Beckereit ${ }^{1} \cdot$ Claus P. W. Zebitz $^{1}$ \\ ${ }^{1}$ Institute of Phytomedicine, University of Hohenheim, 70593 Stuttgart, Germany \\ 2 Present Address: Department of Land Resources and Environmental Science, \\ Montana State University, Bozeman, MT 59717-3120, USA
}

\author{
Claus P. W. Zebitz \\ Claus.Zebitz@uni-hohenheim.de \\ Irina Goleva \\ irgoleva@uni-hohenheim.de \\ Esteban C. Rubio Cadena \\ decaes63@hotmail.com \\ Nar B. Ranabhat \\ nar.ranabhat@msu.montana.edu \\ Caroline Beckereit \\ beckicaro@gmx.de
}

\begin{abstract}
Pollen is offered as alternative or supplementary food for predacious mites; however, it may vary in its nutritional value. Body weight appears a representative parameter to describe food quality. Thus, we assessed the body weight for adults of the generalist mites Amblyseius swirskii, Amblydromalus limonicus, and Neoseiulus cucumeris reared on 22, 12, and 6 pollen species, respectively. In addition, $A$. swirskii and $A$. limonicus was reared on codling moth eggs. In all mite species, female body weight was higher than that of males, ranging between 4.33 and $8.18 \mathrm{lg}$ for A. swirskii, 2.56-6.53 lg for A. limonicus, and 4.66-5.92 lg for N. cucumeris. Male body weight ranged between 1.78 and $3.28 \mathrm{lg}, 1.37-3.06 \mathrm{lg}$, and 2.73-3.03 lg, respectively. Nutritional quality of pollen was neither consistent among the mite species nor among sex, revealing superior quality of Quercus macranthera pollen for females of $A$. swirskii and Tulipa gesneriana pollen for males, Alnus incana pollen for females of A. limonicus and Aesculus hippocastanum pollen for males, and Ae. hippocastanum pollen for both sexes of $\mathrm{N}$. cucumeris. The results are discussed against the background of known or putative pollen chemistry and mite's nutritional physiology.
\end{abstract}




\section{Introduction}

Limitation and quality of either primary, alternative or supplementary food plays a crucial role in development, longevity, and reproduction of predacious mites (Badii et al. 1990; Yao and Chant 1990; Momen 1994; Jung and Croft 2001; Williams et al. 2004; Hussein 2010; Walzer and Schausberger 2013).

Besides these descriptive parameters important for successful biocontrol, food quantity and quality also directly influences body size and biomass, which indirectly determines physical fitness. Smaller males are less competitive during courtship behaviour and less successful in mating compared to bigger ones (Walzer and Schausberger 2011, 2013, 2014). In predator-prey relations, disparity in body size and biomass determines success to subdue a prey (Sabelis 1981; Yao and Chant 1990; Walzer and Schausberger 2008, 2011; Reis et al. 2003). Body size and fitness also affect intraguild competition and result in shifts in species dominance and biocontrol efficacy when several predator species have been released (Polis and Holt 1992; Polis et al. 1989). However, body size, weight and life-table characteristics of phytoseiid mites differ considerably between species and within a species depending on quality of pollen, animal food, or artificial diets (McMurtry and Scriven 1966; Badii et al. 1990; Croft et al. 1999; van Rijn and Tanigoshi 1999; Vantornhout et al. 2004; Momen and El-Laithy 2007; Lorenzon et al. 2012; Goleva and Zebitz 2013; Vangansbeke et al. 2014a, b; Walzer and Schausberger 2014; Nguyen et al. 2014, 2015). However, information on body size or weight dependent on food quality is rare.

In our study, we assessed the significance of nutritional quality of different diets on body weight of the generalist mites Amblyseius swirskii Athias-Henriot, Amblydromalus (Amblyseius, Typhlodromalus) limonicus (Garman \& McGregor) (both type III b), and Neoseiulus cucumeris (Oudemans) (type IIIe, according to McMurtry et al. 2013) (Acari: Phytoseiidae).

\section{Materials and methods}

\section{Food sources}

\section{Pollen}

Pollen of the following anemophilous plants were collected by shedding the flowers: birch (Betula pendula Roth), common cattail (Typha latifolia L.), Scots pine (Pinus sylvestris L.), common walnut (Juglans regia L.), Persian oak (Quercus macranthera Fisch. \& C.A. Mey. ex Hohen.), European beech (Fagus sylvatica L.), hazelnut (Corylus avellana L.), Caucasian walnut (Pterocarya fraxinifolia (Lam.) Spach), common alder (Alnus glutinosa L.), grey alder (Alnus incana (L.) Moench), Japanese alder (Alnus japonica (Thunb.) Steud.), olive (Oleae europaea L.), castor bean (Ricinus communis L.), and maize (Zea mays L.). Pollen of the following entomophilous plants were collected using a brush: horse chestnut (Aesculus hippocastanum L.), princess tree (Paulownia tomentosa (Thunb.) Sieb. \& Zucc.), sunflower (Helianthus annuus L.), apple (Malus domestica Borkh.), dog rose 
(Rosa canina L.), rape (Brassica napus L.), christmas cactus (Schlumbergera sp. (Lem.)) hybrid, tulip (Tulipa gesneriana L.). All pollen were collected from pesticide-free plants in the field, dried for 2 days at room temperature and stored under $-20{ }^{\circ} \mathrm{C}$ until use in the experiments. Pollen of Scots pine was provided by Mr. H. Schneller (LTZ Augustenberg, Dept. of Plant Health and Product Quality). Except maize, sunflower, and C. avellana pollen (all collected in Straubing-Bogen, Bavaria, Germany), and common cattail pollen (supplied by Koppert, Berkel en Rodenrijs, The Netherlands), all pollens were collected on the campus of the University of Hohenheim.

\section{Animal food}

Codling moth [Cydia pomonella (L.) (Lepidoptera, Tortricidae] eggs were collected daily from the oviposition substrate (polythene film) of adults of the laboratory stock and transferred to the experimental arenas by using a fine brush.

\section{Mite rearing}

Amblyseius swirskii and N. cucumeris were purchased from Sautter \& Stepper (Ammerbuch, Germany), and A. limonicus was provided by Koppert. All species were kept in stackable plastic boxes covered with plastic lids and kept in an incubator at $25 \pm 1{ }^{\circ} \mathrm{C}$, 70-80 \% relative humidity and L16:D8 h photoperiod. Amblyseius swirskii and A. limonicus were reared on B. pendula-pollen, and N. cucumeris on pollen of M. domestica (all offered ad libitum), to obtain eggs for the experiments.

\section{Experimental set-up}

All experiments were conducted in an experimental arena following Overmeer (1985) with slight modifications (Goleva and Zebitz 2013; Ranabhat et al. 2014). The sponges used by Overmeer as spacers, were replaced by petri-dishes placed between the plastic dish bottom and a black PVC plate. This PVC plate $(10 \times 15 \times 0.5 \mathrm{~cm})$ was divided into eight arenas of $2 \times 2.5 \mathrm{~cm}$ for experiments with A. swirskii and $N$. cucumeris, and into six arenas of $2 \times 3.5 \mathrm{~cm}$ for A. limonicus. Each arena was separated by moistened filter paper (Munktell and Filtrak, No. 3, Bärenstein, Germany) to supply the mites with water. A strip of insect glue (Heller Raupenleim-Brutonia, Schacht, Germany) mixed with citronella and castor oil, served as repellent to reduce loss of mites without exerting negative side-effects to the mites (Al-Shammery 2011). These experimental units were kept in a separate incubator at the same regimen as given for the stock rearing.

Newly laid eggs $(\leq 16 \mathrm{~h})$ were collected from the rearing plates and 5 eggs were transferred onto each small observation arena on the experimental plate. Pollen was offered ad libitum at larval hatch and replaced every second or third day, and codling moth eggs $(\leq 24 \mathrm{~h}$ ) were supplied daily, always removing the old food by a fine brush. Preimaginal development was assessed in 20 replicates (5 eggs/replicate) for each food source. Each test set was examined twice daily, once in the morning and once in the late afternoon, and the numbers of individuals in the respective developmental stages were recorded. Exuviae of the moulted stages were removed at each observation time.

To obtain a sufficient number of adults for subsequent analysis of body mass, the same procedure was followed in 40-80 replicates without assessing preimaginal development. 
Freshly hatched males and females were randomly chosen from each treatment and killed in a deep-freezer at $-20{ }^{\circ} \mathrm{C}$ for $24 \mathrm{~h}$ for later assessment of body weight.

Adult fresh weight (AFW) was assessed on a micro-balance (Type UMX2 Automated-S Ultra-microbalance, Mettler Toledo, Gießen, Germany).

\section{Statistical analysis}

The obtained data were analyzed using JMP ${ }^{\circledR}$ 11.0.1 software (SAS Institute, Cary, NC, USA). Parametric data were analyzed by the following steps: (1) Generalized linear model (GLM-procedure), (2) oneway-ANOVA with subsequent Tukey-Kramer HSD-test at $\alpha=0.05$, to compare the effects of independent parameters. F, $d f$, and $P$ values were corrected by Welsh-test if variance inhomogeneity was given following Bartlett's test.

The nonparametric mortality data were analysed by a Wilcoxon-test followed by a Wilcoxon-pairwise comparison and oneway-ANOVA with subsequent Tukey-Kramer HSD-test at $\alpha=0.05$.

Predator species was used as additional factor in a GLM-analysis to compare the mortality, developmental time, and adult weight among the three species only in the treatments with identical pollen provision (Ae. hippocastanum, B. pendula, R. communis, Schlumbergera sp., T. gesneriana, Z. mays). Previously published mortality and development data for $A$. swirskii fed with these pollen have been taken from Goleva and Zebitz (2013). Adult weight data for A. swirskii fed with pollen of B. pendula and Z. mays have been taken from Goleva et al. (2014). Since $100 \%$ preimaginal mortality occurred when $N$. cucumeris was fed with pollen of $R$. communis, and A. limonicus was offered pollen of $T$. gesneriana, these pollen were excluded for GLM-analysis for developmental time and adult weight. The respective statistical procedures, and statistical core data are provided in the legends of the tables.

\section{Results}

\section{Preimaginal development and mortality}

Preimaginal development and mortality of all mite species tested was affected by pollen food quality. However, the suitability of pollen as food was not consistent among the mite species (Table 1). Ricinus communis for example was a good food source for A. limonicus with a preimaginal mortality of $2.67 \%$, but $N$. cucumeris suffered from $100 \%$ mortality (Ranabhat et al. 2014). On the other hand, pollen of $T$. gesneriana was a suitable food source for $N$. cucumeris with $12.6 \%$ preimaginal mortality whereas mortality was medium for A. swirskii and completely unsuitable as food for A. limonicus (31.5 and $100 \%$ preimaginal mortality, respectively). Compared to A. swirskii and A. limonicus, performance of $N$. cucumeris was inferior, except on pollen of $T$. gesneriana, when only the pollen offered to all three species was considered. In all species tested, preimaginal development of males was always faster than that of females.

\section{Body weight}

Adult body weight differed significantly between species, food offered and sex (Table 2). Females always had a higher biomass than males regardless of the food source. Depending 


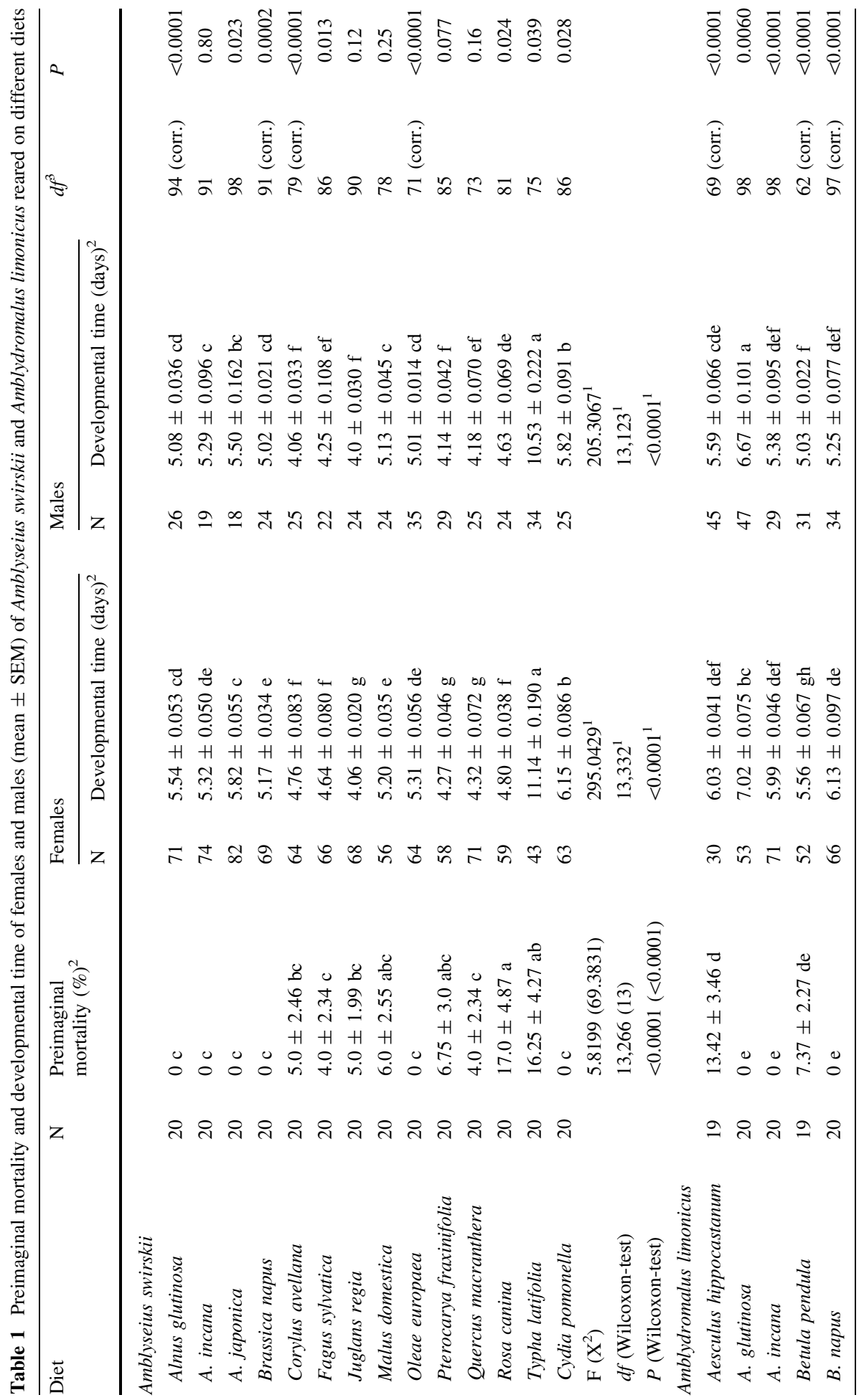




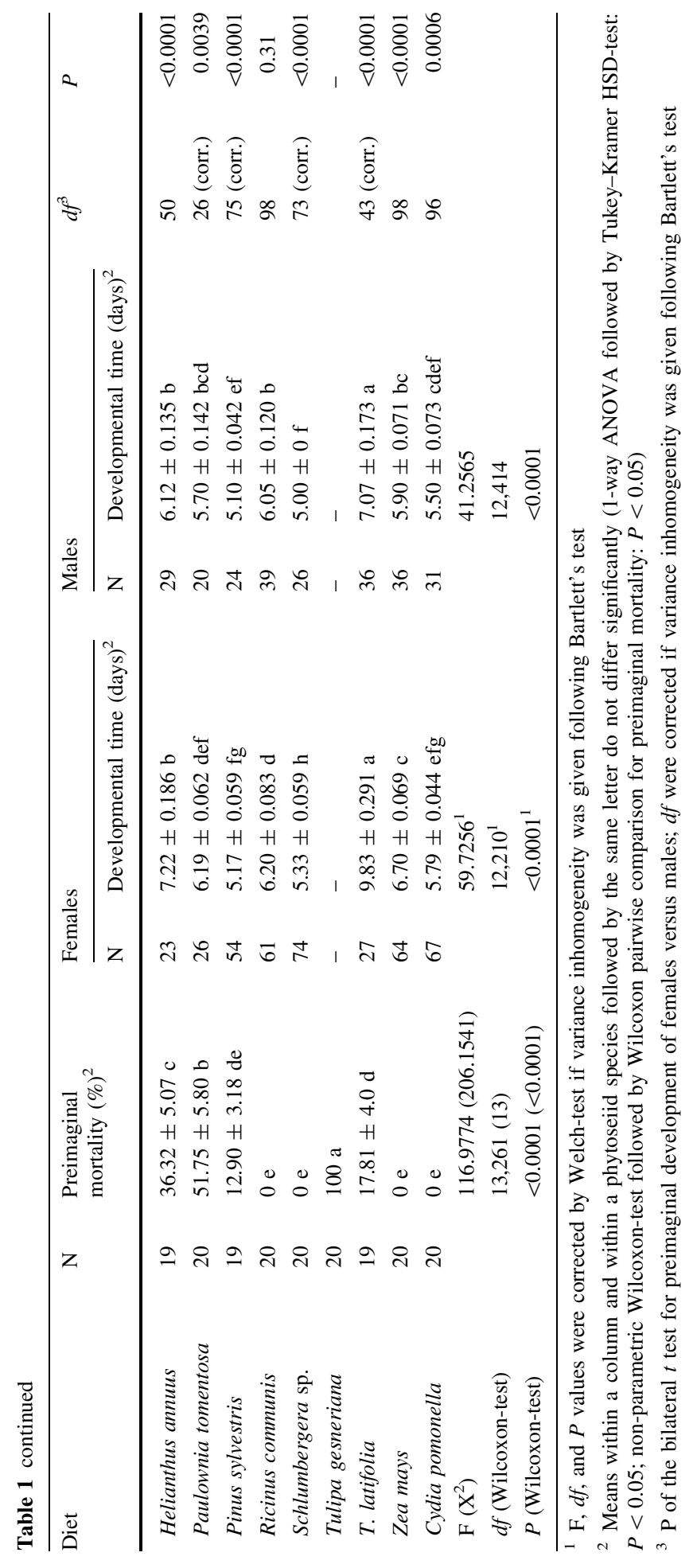


Table 2 Body weight (mean \pm SEM) of Amblyseius swirskii, Amblydromalus limonicus, and Neoseiulus cucumeris reared on different diets

\begin{tabular}{|c|c|c|c|c|c|c|}
\hline \multirow[t]{2}{*}{ Diet } & \multicolumn{2}{|c|}{ Females } & \multicolumn{2}{|c|}{ Males } & \multirow[t]{2}{*}{$d f^{2}$} & \multirow[t]{2}{*}{$P$} \\
\hline & $\mathrm{N}$ & Body weight $(\mu \mathrm{g})$ & $\mathrm{N}$ & Body weight ( $\mu \mathrm{g})$ & & \\
\hline
\end{tabular}

Amblyseius swirskii

Aesculus hippocastanum
Alnus glutinosa
A. incana
A. japonica
Brassica napus
Corylus avellana
Fagus sylvatica
Juglans regia
Malus domestica
Olaea europaea
Pinus sylvestris
Pterocarya fraxinifolia
Quercus macranthera
Ricinus communis
Rosa canina
Schlumbergera sp.
Tulipa gesneriana
Typha latifolia
Cydia pomonella
F $^{1}$
df
$P^{1}$

Amblydromalus limonicus

$\begin{array}{lllllll}\text { Ae. hippocastanum } & 47 & 5.54 \pm 0.094 \mathrm{~b} & 58 & 3.06 \pm 0.045 \mathrm{a} & 67 \text { (corr.) } & <0.0001 \\ \text { A. glutinosa } & 35 & 4.24 \pm 0.222 \mathrm{e} & 26 & 1.39 \pm 0.076 \mathrm{gh} & 42 \text { (corr.) } & <0.0001 \\ \text { A. incana } & 47 & 6.53 \pm 0.042 \mathrm{a} & 48 & 2.30 \pm 0.023 \mathrm{c} & 71 \text { (corr.) } & <0.0001 \\ \text { Betula pendula } & 47 & 5.29 \pm 0.082 \mathrm{bc} & 48 & 2.98 \pm 0.044 \mathrm{ab} & 71 \text { (corr.) } & <0.0001 \\ \text { B. napus } & 48 & 3.93 \pm 0.052 \mathrm{e} & 47 & 2.08 \pm 0.031 \mathrm{cde} & 77 \text { (corr.) } & <0.0001 \\ \text { Helianthus annuus } & 45 & 2.56 \pm 0.031 \mathrm{~g} & 48 & 1.41 \pm 0.034 \mathrm{~h} & 91 & <0.0001 \\ \text { Paulownia tomentosa } & 49 & 3.22 \pm 0.063 \mathrm{f} & 49 & 1.93 \pm 0.056 \mathrm{de} & 96 & <0.0001 \\ \text { P. sylvestris } & 45 & 4.09 \pm 0.073 \mathrm{e} & 49 & 1.67 \pm 0.052 \mathrm{fg} & 81 \text { (corr.) } & <0.0001 \\ \text { R. communis } & 29 & 4.98 \pm 0.105 \mathrm{~cd} & 54 & 1.84 \pm 0.086 \mathrm{ef} & 81 & <0.0001 \\ \text { Schlumbergera sp. } & 48 & 5.59 \pm 0.054 \mathrm{~b} & 48 & 2.14 \pm 0.032 \mathrm{~cd} & 77 \text { (corr.) } & <0.0001 \\ \text { T. latifolia } & 50 & 2.92 \pm 0.076 \mathrm{fg} & 49 & 1.37 \pm 0.051 \mathrm{~h} & 85 \text { (corr.) } & <0.0001 \\ \text { Zea mays } & 45 & 5.51 \pm 0.032 \mathrm{~b} & 48 & 1.97 \pm 0.031 \mathrm{de} & 91 & <0.0001 \\ \text { Cydia pomonella } & 51 & 4.89 \pm 0.092 \mathrm{~d} & 52 & 2.79 \pm 0.088 \mathrm{~b} & 101 & <0.0001 \\ \mathrm{~F}^{1} & & 720.4323 & & 144.7645 & & \\ \text { df }^{1} & & 12,215 & & <2,227 & \end{array}$

\begin{tabular}{ll}
81 (corr.) & $<0.0001$ \\
59 (corr.) & $<0.0001$ \\
74 (corr.) & $<0.0001$ \\
69 (corr.) & $<0.0001$ \\
93 & $<0.0001$ \\
109 (corr.) & $<0.0001$ \\
83 (corr.) & $<0.0001$ \\
138 (corr.) & $<0.0001$ \\
63 (corr.) & $<0.0001$ \\
69 (corr.) & $<0.0001$ \\
60 (corr.) & $<0.0001$ \\
97 (corr.) & $<0.0001$ \\
81 (corr.) & $<0.0001$ \\
82 (corr.) & $<0.0001$ \\
65 (corr.) & $<0.0001$ \\
91 (corr.) & $<0.0001$ \\
91 (corr.) & $<0.0001$ \\
75 (corr.) & $<0.0001$ \\
61 (corr.) & $<0.0001$ \\
& \\
\hline ( & \\
\hline ( & \\
\hline
\end{tabular}

$37 \quad 5.32 \pm 0.108 \mathrm{gh}$

$49 \quad 5.75 \pm 0.079 \mathrm{defg}$

$47 \quad 5.50 \pm 0.074 \mathrm{fgh}$

$50 \quad 6.19 \pm 0.072 \mathrm{~cd}$

$634.33 \pm 0.143 \mathrm{i}$

$476.10 \pm 0.083$ cde

$97 \quad 5.79 \pm 0.068 \mathrm{def}$

$50 \quad 5.81 \pm 0.069 \mathrm{defg}$

$46 \quad 5.19 \pm 0.067 \mathrm{~h}$

$425.63 \pm 0.061 \mathrm{efgh}$

$62 \quad 5.74 \pm 0.121 \mathrm{defg}$

$558.18 \pm 0.109 \mathrm{a}$

$47 \quad 7.11 \pm 0.093 \mathrm{~b}$

$45 \quad 5.92 \pm 0.118$ cdef

$55 \quad 5.39 \pm 0.092 \mathrm{gh}$

$45 \quad 5.81 \pm 0.041 \mathrm{defg}$

$60 \quad 5.18 \pm 0.081 \mathrm{~h}$

46

\subsection{2}

18,345

$<0.0001$

42

48

34

49 62

47

92

47 46

24

57

56

47

47

50

49

25

47

\subsection{3}

18,305

$<0.0001$

$3.02 \pm 0.039 \mathrm{ab}$

0.062 de

$2.57 \pm 0.048 \mathrm{de}$

$\pm 0.040 \mathrm{bcd}$

097 ghi

$\pm 0.047 \mathrm{cde}$

$0.049 \mathrm{a}$

056 de

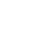

. 
Table 2 continued

\begin{tabular}{|c|c|c|c|c|c|c|}
\hline \multirow[t]{2}{*}{ Diet } & \multicolumn{2}{|c|}{ Females } & \multicolumn{2}{|c|}{ Males } & \multirow[t]{2}{*}{$d f^{2}$} & \multirow[t]{2}{*}{$P$} \\
\hline & $\mathrm{N}$ & Body weight $(\mu g)$ & $\mathrm{N}$ & Body weight $(\mu g)$ & & \\
\hline \multicolumn{7}{|l|}{ Neoseiulus cucumeris } \\
\hline Ae. hippocastanum & 50 & $5.92 \pm 0.081 \mathrm{a}$ & 48 & $3.03 \pm 0.036 \mathrm{a}$ & 70 (corr.) & $<0.0001$ \\
\hline B. pendula & 49 & $4.66 \pm 0.058 \mathrm{~d}$ & 47 & $2.73 \pm 0.034 \mathrm{~b}$ & 75 (corr.) & $<0.0001$ \\
\hline M. domestica & 49 & $4.78 \pm 0.054 \mathrm{~cd}$ & 47 & $2.69 \pm 0.040 \mathrm{~b}$ & 85 (corr.) & $<0.0001$ \\
\hline Schlumbergera sp. & 47 & $4.97 \pm 0.057 \mathrm{c}$ & 48 & $2.99 \pm 0.054 \mathrm{a}$ & 91 & $<0.0001$ \\
\hline T. gesneriana & 47 & $5.27 \pm 0.065 \mathrm{~b}$ & 48 & $3.02 \pm 0.055 \mathrm{a}$ & 93 & $<0.0001$ \\
\hline Zea mays & 50 & $4.76 \pm 0.060 \mathrm{~cd}$ & 49 & $2.57 \pm 0.049 \mathrm{~b}$ & 92 & $<0.0001$ \\
\hline $\mathrm{F}^{1}$ & & 41.2054 & & 19.2973 & & \\
\hline$d f^{1}$ & & 5133 & & 5131 & & \\
\hline$P^{1}$ & & $<0.0001$ & & $<0.0001$ & & \\
\hline
\end{tabular}

Means within a column and within a phytoseiid species followed by the same letter do not differ significantly (1-way ANOVA followed by Tukey-Kramer HSD-test: $P<0.05$ )

${ }^{1} \mathrm{~F}, d f$, and $P$ values were corrected by Welch-ANOVA-test because of variance inhomogeneity after Bartlett's test

${ }^{2} P$ of the bilateral $t$ test for body weight of females versus males; $d f$ were corrected if variance inhomogeneity was given following Bartlett's test

on mite species and food, mean body weight varied widely in females between $4.12 \mu \mathrm{g}$ for A. limonicus fed with $P$. sylvestris and $8.18 \mu \mathrm{g}$ for $A$. swirskii fed with $Q$. macranthera, and in males ranging from $1.39 \mu \mathrm{g}$ for A. limonicus fed with A. glutinosa to $3.68 \mu \mathrm{g}$ for $A$. swirskii fed with $P$. tomentosa. Only A. limonicus females fed on P. tomentosa, T. latifolia, and $H$. annuus pollen had a low mean weight $(3.19,2.90$, and $2.54 \mu \mathrm{g}$, respectively) similar or only slightly higher than the mean male body weight of the three species tested. Feeding A. limonicus with $T$. gesneriana and $N$. cucumeris with pollen of $R$. communis proved to be an unsuitable food for this mite species, resulting in $100 \%$ preimaginal mortality.

Amblyseius swirskii female mean body weight ranged between 4.33 and $8.18 \mu \mathrm{g}$ when fed with $C$. avellana and $Q$. macranthera, respectively, and that of males varied between 1.78 and 3.66 when fed with $P$. fraxinifolia and $P$. tomentosa, respectively. Thus, the best food resulted in a $2 \times$ higher body weight of both sexes compared to the poorest food source. Feeding on $C$. pomonella eggs as animal food source resulted in high mean body weights in both, females and males of A. swirskii and A. limonicus. However, some pollen had a higher nutritional value for the mite species than codling moth eggs (Table 2).

Although the number of pollen species tested was not the same, in contrast to A. swirskii the highest female and male mean body weight of A. limonicus (6.54 and $3.07 \mu \mathrm{g}$, respectively) was almost $2.5 \times$ higher when reared on the most valuable food compared to the weight obtained when fed with the poorest food. However, also in this species, the ranking of the different food sources was not consistent between females and males. The nutritional value of related Alnus-species differed between pollen species and also between A. swirskii and A. limonicus (Table 2). Feeding pollen of T. gesneriana led to $100 \%$ preimaginal mortality, whereas for A. swirskii and N. cucumeris this pollen was a food source of good quality. 
Due to the smaller number of pollen tested, body weight of female and male $N$. cucumeris showed few significant differences ranging between 4.7 and $5.92 \mu \mathrm{g}$ for females and 2.55 and $3.04 \mu \mathrm{g}$ for males when fed with pollens which were found also among the best food for both A. swirskii and A. limonicus.

The multiple ANOVA by GLM-analysis, with predator species as additional factor, revealed significantly different performances of the mite species when fed with identical pollen. Factor combinations of pollen with species or sex also resulted in highly significant interactions (Table 3).

\section{Discussion}

Biological parameters used to describe the quality of predators such as developmental time, mortality, fecundity, reproduction period, longevity, predation potential and body size are tools to estimate the suitability of different factitious prey species, alternative food, or an artificial diet for mass rearing of predators (Croft et al. 1999; Grenier and De Clercq 2003; van Lenteren 2003; Callebaut et al. 2004). Not only the physical fitness and longevity are, to a certain extent, dependent on body weight and energy availability, which are determined by food quality, but also reproduction-related parameters depend on female size. The total number of eggs per female Phytoseiulus persimilis Athias-Henriot was positively correlated with the size of females. Even in the $F_{1}$-generation, the mean dorsal

Table 3 Analysis of variance (GLM: General Linear Model, normal distribution, link: identity, full module test, maximumlikelihood) of preimaginal mortality, developmental time, and adult weight of Amblyseius swirskii, Amblydromalus limonicus, and Neoseiulus cucumeris, with identical pollen provision (Aesculus hippocastanum, Betula pendula, Ricinus communis, Schlumbergera sp., Tulipa gesneriana, and Zea mays)

1 Pollen of $R$. communis and $T$. gesneriana excluded

\begin{tabular}{lrrrr}
\hline & $\mathrm{N}$ & $d f$ & \multicolumn{1}{l}{$\mathrm{X}^{2}$} & \multicolumn{1}{l}{$P$} \\
\hline Preimaginal mortality & & & & \\
Full model & 372 & 17 & 668.5525 & $<0.0001$ \\
Source & & & & \\
$\quad$ Species & & 2 & 158.9547 & $<0.0001$ \\
$\quad$ Pollen & & 5 & 249.1534 & $<0.0001$ \\
$\quad$ Species $\times$ pollen & & 10 & 525.0332 & $<0.0001$ \\
Developmental time & & & & \\
Full model & 947 & 15 & 986.7799 & $<0.0001$ \\
Source & & & & \\
Species & & 2 & 600.3407 & $<0.0001$ \\
Pollen ${ }^{1}$ & & 3 & 408.3027 & $<0.0001$ \\
Sex & & 1 & 75.6579 & $<0.0001$ \\
Species $\times$ pollen & & 6 & 176.1114 & $<0.0001$ \\
Sex $\times$ pollen & & 3 & 11.1382 & 0.011 \\
Adult weight & & & & \\
Full model & 1168 & 15 & 2640.750 & $<0.0001$ \\
Source & & & & \\
Species & & 2 & 22.6254 & $<0.0001$ \\
Pollen ${ }^{1}$ & & 3 & 233.4645 & $<0.0001$ \\
Sex & & 1 & 2573.5409 & $<0.0001$ \\
Species $\times$ pollen & & 6 & 223.3406 & $<0.0001$ \\
Sex $\times$ pollen & & 3 & 51.1585 & $<0.0001$ \\
\hline & & & &
\end{tabular}


shield length of females was positively correlated with the size of the parental females (Walzer and Schausberger 2013, 2014).

The phytoseiid mite species differ in size (Collyer 1982; Beard 2001; Zhang 2003), which may bear the risk of misinterpretation of absolute body weight differences between species, because mean body weight is directly correlated with body length (Goleva et al. 2014). However, body size of A. limonicus, N. cucumeris, and A. swirskii do not differ so much, ranging between 0.37 and $0.40 \mathrm{~mm}$ (Zhang 2003), and a direct comparison of body weight of these species should be possible.

Although each pollen offered was accepted and consumed by the three phytoseiid species tested, the nutritional value was not consistent for the three species. For example, a highly valuable food for $A$. swirskii must not necessarily have the same quality for another phytoseiid species. Comparing the ranks of suitability and quality of the five pollen tested with all three mite species, pollen of castor bean ranked first and fifth in female weight of A. swirskii and A. limonicus, respectively, but was absolutely unsuitable for $N$. cucumeris suffering from $100 \%$ preimaginal mortality (Ranabhat et al. 2014).

Sexual dimorphism in phytoseiid mites is well described (Collyer 1982; Beard 2001) and, thus, in all mite species tested, females were generally heavier than males when fed with the same food. However, the relative difference between female and male weight was not always the same. For example, males of A. swirskii fed with pollen of A. hippocastanum and $Q$. macranthera reached 55.8 and $23.6 \%$ of the female weight. Nearly similar differences could be found for A. limonicus fed with $P$. tomentosa and A. glutinosa-pollen, where males gained a body weight of 61.1 and $32.8 \%$ of the female weight, respectively.

It may be assumed that males and females have different nutritional demands, which could not served by some pollen, either due to a poor metabolisation or lack of nutrients. Pollen of Ae. hippocastanum had the highest nutritional quality for all three mite species tested. Inferior nutritional quality of T. latifolia pollen has been reported also by Vangansbeke et al. (2014a, 2014b) for A. limonicus females compared to animal prey, being the smallest when fed with $T$. latifolia pollen compared to that of females fed with Ephestia kuehniella Zeller eggs or Artemia franciscana Kellogg cysts. Also females of A. swirskii reached a low body weight only when fed with $T$. latifolia whereas other pollen or codling moth eggs had a superior food quality.

Although cattail pollen has often been attributed a high nutritional quality for predacious mites, our results indicate that cattail pollen either collected at different years and/or possibly handled differently differs in food quality. Furthermore, food quality for predacious mites differs among mite species in a direct comparison and not only after comparison of literature data (Nguyen et al. 2015).

The most striking differences in food quality were found for pollen of $R$. communis and T. gesneriana. Pollen of castor bean was a suitable food source only for A. swirskii and A. limonicus, whereas $N$. cucumeris suffered from $100 \%$ preimaginal mortality (Ranabhat et al. 2014). On the other hand, A. limonicus could not develop into adults when reared on pollen of $T$. gesneriana. Only A. swirskii could develop when fed with both the pollen. Compared with A. limonicus and $N$. cucumeris, A. swirskii is adapted to a wider range of pollen as alternative food source.

The significant effects of single factors and factor combinations on preimaginal mortality, developmental time, and adult weight of mites fed with identical pollen indicate that, firstly, the nutritional value of a food source for a given mite species cannot be generalized and any food source has to be tested independently. Secondly, it can be concluded that the mite species are differently adapted to pollen, which may depend on a species-specific equipment of metabolizing enzymes or differences in their activity. A possible explanation 
for differences in pollen suitability may be found in a better adaptation of mites to pollen of autochthonous plant species in the same area of distribution, e.g. $Q$. macranthera, $R$. communis and A. swirskii, which may explain the good nutritional quality of their pollen for this mite species. On the other hand, N. cucumeris as a litter-dwelling species should also be adapted to a wide range of food sources, such as decaying organic matter or small soil- and litter-inhabiting arthropod species.

Reviews on pollen chemistry mainly report average concentrations of nutrients, such as proteins, nitrogen, amino acids, lipids, carbohydrates, and sterols of few taxa (Todd and Bretherick 1942; Stanley and Linskens 1974; Rabie et al. 1983; Day et al. 1990; Roulston and Cane 2000; Patt et al. 2003; Somerville and Nicol 2006; Li et al. 2007; You et al. 2007; Campos et al. 2008).

Because of lacking detailed information on pollen chemistry and a very poor knowledge of mite's nutritional physiology, the nutritional value of pollen and digestive or metabolizing processes in mites can only be assumed. Also calculations of food digestibility and conversion indices as used for insect nutrition studies (Waldbauer 1968), are elusive in mites due to their small size and biomass. Indirect parameters, such as digestive efficiency estimated for mites by counting empty pollen grains (Flechtmann and McMurtry 1992), are not very helpful to discuss the nutritional value of pollen or other mite's food.

Whereas proteins, carbohydrates, amino acids and lipids can be taken in toto as nutrients and digestion and metabolisation should be unproblematic for the phytoseiids, detoxification of secondary compounds in pollen, such as alkaloids, flavonoids, or saponins (Stanley and Linskens 1974; Bonvehi et al. 2001; Roth et al. 2008) depends on the equipment of the mite species or strains with metabolizing enzymes. Particularly the multifunctional oxidases (mfo), esterases, or glutathione-S-transferases, are known to be responsible for food adaptations in herbivorous insects or are generally involved in the detoxification of xenobiotics. Furthermore, pollen, like that of Z. mays, may contain quercetin, which is an effective protease-inhibitor, interfering with protein digestion and negatively affecting food conversion although a high protein content may suggest high suitability of a pollen as food source (Larsen 1971; Stanley and Linskens 1974; Barbehenn and Constabel 2011).

For a better understanding of phytoseiid nutrition, particularly on plant material, it is inevitable to know more about the chemical composition of pollen and the nutritional physiology of these mites.

Acknowledgments The authors are indebted to Greta Ott and Josef Schreiber for their help in pollen collection. This study was in part supported by a $\mathrm{PhD}$ grant from the European commission Erasmus Mundus External Cooperation Window (IAMONET-RU).

\section{References}

Al-Shammery KA (2011) Plant pollen as an alternative food source for rearing Euseius scutalis (Acari: Phytoseiidae) in Hail, Saudi Arabia. J Entomol 8:365-374

Badii MH, McMurtry JA, Johnson HG (1990) Comparative life-history studies on the predaceous mites Typhlodromus annectens and T. porresi (Acari: Mesostigmata: Phytoseiidae). Exp Appl Acarol 10:129-136

Barbehenn RV, Constabel CP (2011) Tannins in plant-herbivore interactions. Phytochemistry $72: 1151-1565$

Beard JJ (2001) A review of the Australian Neoseiulus Hughes and Typhlodromips de Leon (Acari: Phytoseiidae: Amblyseiinae). Invertebr Taxon 15:73-158 
Bonvehi SJ, Torrento MS, Lorente EG (2001) Evaluation of polyphenolic and flavonoid compounds in honeybee-collected pollen produced in Spain. J Agric Food Chem 49:1848-1853

Callebaut B, van Baal E, Vandekerkhove B, Bolckmans K, De Clercq P (2004) A fecundity test for assessing the quality of Macrolophus caliginosus reared on artificial diets. Parasitica 60:9-14

Campos MGR, Bogdanov S, de Almeida-Muradian LB, Szczesna T, Mancebo Y, Frigerio C, Ferreira F (2008) Pollen composition and standardisation of analytical methods. J Apic Res 47:156-163

Collyer E (1982) The Phytoseiidae of New Zealand (Acarina) 1. The genera Typhlodromus and Amblyseius-keys and new species. N Z J Zool 9:185-206

Croft BA, Luh HK, Schausberger P (1999) Larval size relative to larval feeding, cannibalism of larvae, egg or adult female size and larval-adult setal patterns among 13 phytoseiid mite species. Exp Appl Acarol 23:599-610

Day S, Beyer R, Mercer A, Ogden S (1990) The nutrient composition of honeybee-collected pollen in Otago, New Zealand. J Apic Res 29:138-146

Flechtmann CHW, McMurtry JA (1992) Studies on how phytoseiid mites feed on spider mites and pollen. Int J Acarol 18:157-162

Goleva I, Zebitz CPW (2013) Suitability of different pollen as alternative food for the predatory mite Amblyseius swirskii Athias-Henriot (Acari, Phytoseiidae). Exp Appl Acarol 61:259-283

Goleva I, Gerken S, Zebitz CPW (2014) Influence of pollen feeding on body weight and body size of the predatory mite Amblyseius swirskii Athias-Henriot (Acari, Phytoseiidae). J Plant Dis Protect 121:219-222

Grenier S, De Clercq P (2003) Comparison of artificially vs. naturally reared natural enemies and their potential for use in biological control. In: van Lenteren JC (ed) Quality control and the production of biological control agents: theory and testing procedures. UK, International CAB, pp 115-131

Hussein H (2010) Fertilisation and prey deprivation affecting reproduction, life history and life table of the predacious mite Paraseiulus talbii (Athias-Henriot) (Acari: Phytoseiidae). Arch Phytopathol Plant Protect 43:241-250

Jung C, Croft BA (2001) Aerial dispersal of phytoseiid mites (Acari: Phytoseiidae): estimating falling speed and dispersal distance of adult females. Oikos 94:182-190

Larsen RL (1971) Glucosylation of quercetin by a maize pollen enzyme. Phytochemistry 10:3073-3076

Li L, Tsao R, Yang R, Kramer JKG, Hernandez M (2007) Fatty acid profiles, tocopherol contents, and antioxidant activities of heartnut (Juglans ailanthifolia var. cordiformis) and Persian walnut (Juglans regia L.). J Agric Food Chem 55:1164-1169

Lorenzon M, Pozzebon A, Duso C (2012) Effects of potential food sources on biological and demographic parameters of the predatory mites Kampimodromus aberrans, Typhlodromus pyri and Amblyseius andersoni. Exp Appl Acarol 58:259-278

McMurtry JA, Scriven GT (1966) Effects of artificial foods on reproduction and development of four species of phytoseiid mites. Ann Entomol Soc Amer 59:267-269

McMurtry JA, de Moraes GJ, Sourassou NF (2013) Revision of the lifestyles of phytoseiid mites (Acari: Phytoseiidae) and implications for biological control strategies. Syst Appl Acarol 18:297-320

Momen FM (1994) Fertilisation and starvation affecting reproduction in Amblyseius barkeri (Hughes) (Acari, Phytoseiidae). Anz Schädl Pflanzenschutz Umweltschutz 67:130-134

Momen FM, El-Laithy AY (2007) Suitability of the flour moth Ephestia kuehniella (Lepidoptera: Pyralidae) for three predatory phytoseiid mites (Acari: Phytoseiidae) in Egypt. Int J Trop Insect Sci 27:102-107

Nguyen DT, Vangansbeke D, De Clercq P (2014) Solid artificial diets for the phytoseiid predator Amblyseius swirskii. Biocontrol 59:719-727

Nguyen DT, Vangansbeke D, De Clercq P (2015) Performance of four species of phytoseiid mites on artificial and natural diets. Biol Control 80:56-62

Overmeer WPJ (1985) Rearing and handling. In: Helle W, Sabelis MW (eds) Spider mites, vol 1B. Elsevier, Amsterdam, pp 161-170

Patt JM, Wainright SC, Hamilton GC, Whittinghill D, Bosley K, Dietrick J, Lashomb JH (2003) Assimilation of carbon and nitrogen from pollen and nectar by a predaceous larva and its effects on growth and development. Ecol Entomol 28:717-728

Polis GA, Holt RD (1992) Intraguild predation: the dynamics of complex trophic interactions. Trends Ecol Evol 7:151-154

Polis GA, Myers CA, Holt RD (1989) The ecology and evolution of intraguild predation-potential competitors that eat each other. Annu Rev Ecol Syst 20:297-330

Rabie AL, Wells JD, Dent LK (1983) The nitrogen content of pollen protein. J Apic Res 22:119-123

Ranabhat NB, Goleva I, Zebitz CPW (2014) Life tables of Neoseiulus cucumeris exclusively fed with seven different pollens. Biocontrol 59:195-203 
Reis PR, Sousa EO, Teodoro AV, Neto MP (2003) Effect of prey density on the functional and numerical responses of two species of predaceous mites (Acari: Phytoseiidae). Neotrop Entomol 32:461-467

Roth L, Daunderer M, Kormann K (2008) Giftpflanzen-Pflanzengifte, 5th edn. Nikol Verlagsges. mbH, Hamburg

Roulston T, Cane JH (2000) Pollen nutritional content and digestibility for animals. Plant Syst Evol 222:187-209

Sabelis MW (1981) Biological control of two-spotted spider mites using phytoseiid predators. Part 1. Modelling the predator-prey interaction at the individual level. Agric Res Rpt 910. Wageningen, Netherlands, Pudoc 242

Schausberger P, Croft BA (1999) Activity, feeding and development among larvae of specialist and generalist phytoseiid mite species (Acari: Phytoseiidae). Environ Entomol 28:322-329

Somerville DC, Nicol HI (2006) Crude protein and amino acid composition of honey bee-collected pollen pellets from south-east Australia and a note on laboratory disparity. Aust J Exp Agric 46:141-149

Stanley RG, Linskens HG (1974) Pollen, biology, biochemistry and management. Springer, Berlin

Todd FE, Bretherick O (1942) The composition of pollens. J Econ Entomol 3:312-317

van Lenteren JC (2003) Commercial availability of biological control agents. In: van Lenteren JC (ed) Quality control and production of biological control agents: theory and testing procedures. CABI Publishing, Wallingford, pp 167-178

van Rijn PCJ, Tanigoshi LK (1999) Pollen as food for the predatory mites Iphiseius degenerans and Neoseiulus cucumeris (Acari: Phytoseiidae): dietary range and life history. Exp Appl Acarol 23:785-802

Vangansbeke D, Nguyen DT, Audenaert J, Verhoeven R, Gobin B, Tirry L, De Clercq P (2014a) Food supplementation affects interactions between a phytoseiid predator and its omnivorous prey. Biol Control 76:95-100

Vangansbeke D, Nguyen DT, Audenaert J, Verhoeven R, Gobin B, Tirry L, De Clercq P (2014b) Performance of the predatory mite Amblydromalus limonicus on factitious foods. Biocontrol 59:67-77

Vantornhout I, Minnaert HL, Tirry L, de Clercq P (2004) Effect of pollen, natural prey and factitious prey on the development of Iphiseius degenerans. Biocontrol 49:627-644

Waldbauer GP (1968) The consumption and utilization of food by insects. Adv Insect Physiol 5:229-288

Walzer A, Schausberger P (2008) Phenotypic plasticity in developmental time and body size induced by food limitation in three phytoseiid mite species. In: Bertrand M, Kreiter S, McCoy KD, Migeon A, Navajas M, Tixier M-S, Vial L (eds) Integrative acarology_Proceedings of the Sixth Congress of European Association of Acarologists, European Association of Acarologists, Montpellier, pp 130-135

Walzer A, Schausberger P (2011) Sex-specific developmental plasticity of generalist and specialist predatory mites (Acari: Phytoseiidae) in response to food stress. Biol J Linn Soc 102:650-660

Walzer A, Schausberger P (2013) Intra- and trans-generational costs of reduced female body size caused by food limitation early in life in mites. PLOS One 8:e79089

Walzer A, Schausberger P (2014) Canalization of body size matters for lifetime reproductive success of male predatory mites (Acari: Phytoseiidae). Biol J Linn Soc Lond 111:889-899

Williams MEC, Kravar-Garde L, Fenlon JS, Sunderland KD (2004) Phytoseiid mites in protected crops: the effect of humidity and food availability on egg hatch and adult life span of Iphiseius degenerans, Neoseiulus cucumeris, N. californicus and Phytoseiulus persimilis (Acari: Phytoseiidae). Exp Appl Acarol 32:1-13

Yao DS, Chant DA (1990) Changes in body weight of two species of predatory mites (Acarina: Phytoseiidae) as a consequence of feeding in an interactive system. Exp Appl Acarol 8:195-220

You JM, Zhu F, Zhao WC, Zhao XE, Suo YR, Liu SJ (2007) Analysis of saturated free fatty acids from pollen by HPLC with fluorescence detection. Eur J Lipid Sci Technol 109:225-236

Zhang ZQ (2003) Mites in greenhouse: identification, biology and control. CABI Publishing Press, Cambridge 235 